DOI:10.24193/tras.54E.5

Published First Online: 2018/06/29

\section{INFLUENCE OF SOCIAL CAPITAL ON COMMUNITY RESILIENCE IN THE CASE OF EMERGENCY SITUATIONS IN ROMANIA*}

\section{Bianca RADU}

\section{Bianca RADU}

Lecturer, PhD, Department of Public Administration and Management, Faculty of Political, Administrative and Communication Sciences, Babeș-Bolyai University, Cluj-Napoca, Romania Tel: 0040-726-109.075

\section{Abstract}

Researches have highlighted the importance of social capital existing in a community for post-disaster recovery and therefore for strengthening the social infrastructure of a community in order to increase the level of resilience to hazards. The article analyzes the manifestations of cognitive social capital before, during and after a disaster, with the aim of identifying whether communities where people tend to help each other more are perceived to be more resilient in the case of natural and human caused disasters.

The analysis is based on a research conducted at the national level on a sample of 277 City Halls from Romania between September and November 2016. The findings of the research show that people provide help to others with which they are emotionally connected, such as relatives and neighbors. Residents tend to provide help in the form of sharing information and contributing to saving lives and the belongings of other people; they provide emotional support and carrying for children, disabled or elderly people. The research found an association between different forms of community support and the perception on community resilience.

Keywords: community resilience, hazards, social capital, citizens' participation, Romania.
E-mail: bianca.radu@fspac.ro

* The article has been prepared with the support of the Grant for Young Researchers GTC no. 31811 funded by BabeșBolyai University between 2016 and 2017. 


\section{Introduction}

The paper aims to analyze the characteristics of a community that help it recover after a major disruption, whether it is a natural disaster (such as flood, fire or earthquake) or a social upheaval (such as a terrorist attack or a major work accident). In particular, we aimed to analyze if citizens' involvement and support throughout an emergency situation makes people perceive a community as being more resilient. The paper analyzes the case of Romania, a country that faces recurrent natural hazards and other forms of disasters. A plane accident from January 2014 in which two doctors died generated lively debates about the slow and unorganized intervention of public institutions in saving the victims and highlighted the major contribution that local people had in finding and rescuing the victims. In the summer of the same year, severe floods damaged over 2,300 homes. On October 30, 2015 a deadly fire took place in the 'Colectiv' club in Bucharest, killing 26 people on site and other 38 in hospitals; it was one of the deadliest fires in the history of Romania, and it caused people up rise against the government, which generated the resignation of the prime minister and of the entire cabinet at that time. The 'Colectiv' accident showed the solidarity of people who helped rescue the victims, and who mobilized massively afterwards to donate blood and money for the victims. These examples show the diversity and the severe impact of natural or man-made hazards that took place in Romania, and that citizens' involvement in search and rescue activities was beneficial. However, the interaction between emergency personnel and unorganized volunteers is challenging and sometimes risky, as it will be later shown.

Even though Romania has a well-functioning warning system in the case of natural and man-made hazards, local authorities are criticized for insufficient infrastructure investments that would prevent and reduce the impact of disasters. For example, the historical buildings in the downtown area of Bucharest (the capital city) have a high risk of collapsing in the case of an earthquake (Armaș, 2008, 2012). Important steps were made toward building and strengthening the institutional capacity of public institutions to intervene in the case of emergency situations; for example, in 2001 a national legislation was passed requiring all local authorities to establish a Voluntary Service for Emergency Situations at the level of each community in order to prepare and organize the intervention efforts in the case of disasters or major accidents. Starting with 2008, a law requires all house owners to purchase a mandatory insurance for their properties (house and land) covering natural disaster, such as earthquake, flooding and landslide; nonetheless, the level of conformity among households is low (Hanger et al., 2018). In addition, investments were made in strengthening the intervention capacity of inspectorates for emergency situations and the reaction time in the case of hazards. However, natural disasters continue to produce major damages in Romania. In this context, we analyze the influence of social capital on the resilience of communities affected by disasters. 


\section{Literature review}

Community disaster resilience refers to the ability of a community 'to anticipate and reduce risks and vulnerabilities and increase the adaptive capacity and the potential for transformative learning in the face of disasters and other major changes' (Cox and Hamlen, 2015, p. 221). Orencio and Fujii (2013), Masterson et al. (2014) and Aldrich (2011) highlight that a resilient community succeeds to maintain its structure and functions after disaster, while Norris et al. (2008) argue that a resilient community might not return to the state previous to the disaster, but to a different state that it is better adapted to new conditions.

There are two different elements that help a community overcome an emergency situation, physical and perceptual. Physical elements refer to infrastructure, economic resources, availability and access to services. Individuals' perceptions of their community include elements such as social trust, leadership and previous experiences with crises (Leykin et al., 2013, p. 314).

Cheshire, Esparcia and Shucksmith (2015, p. 11) classified the approaches toward conceptualizing community resilience in three categories based on the perspective on the trajectory after disruption: engineering, ecological and evolutionary. From an engineering approach, a community is resilient if it returns back to its pre-crisis state. The ecological perspective views a resilient community as returning to a new equilibrium state, while the evolutionary resilience is characterized by change into a new state as response to disruption.

Kimhi (2016) has highlighted three different levels of social resilience: individual, community and national. Individual resilience refers to the capacity of individuals to cope with periods of distress. Community resilience incorporates both objective and subjective components; objective components refer to caring for physical aspects of a community, such as water, food and physical protection, while subjective components of resilience refer to the citizens' perceptions of the threats or the availability of resources, social cohesion and trust in elected officials (Kimhi, 2016, p. 166). National resilience is based on maintaining four social components (patriotism, optimism, social integration and trust in political and public institutions) during times of conflict (Kimhi, 2016, p. 166).

In the recent years, researchers have analyzed community resilience from the perspective of the characteristics that make a community resilient (Adger, 2000; Norris et al., 2008; Meerow, Newell and Stults, 2016; Besser, 2013; Buckle, 2006; Crowe, Foley and Collier, 2016; Maguire and Cartwright, 2008); others aimed to measure community resilience by using different indexes and indicators (Leykin et al., 2013; Cox and Hamlen, 2015; Orencio and Fujii, 2013; Cutter, Burton and Emrich, 2010; Hung et al., 2016; Sherrieb, Norris and Galea, 2010).

Communities have different types of capitals that influence their resilience to natural disasters, such as: geographic capital, economic capital, institutional capital, human capital, social capital, information and communication capital (Sherrib, Norris and Galea, 2010; Radu, 2015). There are more voices that advocate for strengthen- 
ing the social infrastructure of a community for natural disasters mitigation (Aldrich, 2010; Aldrich and Meyer, 2015; Nakagawa and Shaw, 2004; Chamlee-Wright and Storr, 2011; Hawke, Girard and Carr, 2016). In the same vein, Chamlee-Wright (2010) urges to switch the focus on analyzing post-disaster recovery from the assistance provided by national and regional agencies to the role played by the social capital existing in the community. However, the focus on strengthening social capital is more suitable for developed countries that already have a robust emergency system, and less for developing countries.

Researches on natural disasters have highlighted the importance of social capital for the preparedness, response and recovery (Islam and Walkerden, 2014; Bihari and Ryan, 2012; Nirupa and Maula, 2013; Storr and Haeffele-Balch, 2012). Chamlee-Wright and Storr (2011) analyzed the post-disaster recovery strategies employed by residents of St. Bernard Parish, USA after Hurricane Katrina and found that residents who returned after the hurricane embraced a self-reliant strategy on their own efforts, and they activated the net of family and neighborhood relations to rebuild the community; the residents perceived themselves as being able to recover the community. The strategy proved to be successful in a context in which state and federal assistance was slow.

Studies have also analyzed different dimensions of social capital that manifest themselves during the period of natural disaster recovery. For example, Uphoff apud Sherrib, Norris and Galea (2010) distinguishes between structural and cognitive social capital. Structural social capital refers to different forms of community organizations and networks, while cognitive social capital refers to norms, values, attitudes and beliefs that encourage cooperation among community residents.

Social capital refers to both received and perceived social support (Norris et al., 2008); perceived support refers to the belief that help can be received if needed, while the received support refers to actual help that a person received. Aldrich (2014) makes the distinction between financial and non-financial support that can be acquired through different networks of social capital. Financial support refers to loans that are given to families in need by their relatives, friends or other members of the community. Non-financial support refers to physical help for search and rescue, debris removal, sheltering, providing information, child or elderly care or emotional support. Similarly, Kimhi (2016) distinguishes between objective and subjective components of the social capital that strengthen the degree of community resilience during natural disasters. The author highlights the need to care for physical needs such as food, water, shelter (that he calls objective components of a community), and social cohesion, trust, personal attitudes, perceptions, feelings, that can be instrumental for faster recovery.

Social support can come from family, friends, neighbors, agencies, public institutions, non-governmental organizations, etc. Studies have shown that the larger the number of one's social connections, the more likely to receive support. From a network perspective, Aldrich and Meyer (2015) distinguish between three types of social 
ties: bonding, bridging and linking. Bonding ties refer to the connections with people who are emotionally close, such as family and friends. Bridging social capital comes from the membership in different organizations, such as civic and professional organizations, political parties, religious groups. Linking ties describe the formal and institutionalized connections between regular citizens and those in power. Aldrich (2011) found that communities with strong bonding and linking ties are more resilient to disasters. Connections with people outside damaged communities can provide critical resources for surviving, such as food, shelter, tools and information. Linking social capital is important for voicing the needs of residents and collaborating with the public institutions responsible with rescue and mitigation actions.

Norris et al. (2008) analyzed from a theoretical perspective the set of capacities that make a community resilient to disasters, and distinguished between three key psychological dimensions of social capital, namely sense of community, place attachment and citizen participation. Place attachment refers to the emotional connection to a city or a neighborhood, and it is important in post-disaster recovery because it fosters citizens' efforts to revitalize the community. Chamlee-Wright and Storr (2011) found that the sense of community and place attachment were important determinants for residents who wanted to return in the city to rebuild their houses after Hurricane Katrina. Similarly, Leykin et al. (2013), studying 15 small and medium size communities throughout Israel during 2011-2012, found that the self-reliant citizens attached to their city were the key ingredients for resilient communities. The research conducted by Spialek et al. (2016) on residents of Washington and Pekin, Illinois affected by the 2013 tornadoes found that a greater sense of belonging had important benefits for communities recovering from disasters.

Even though, before and in the aftermath of emergency situation the support of social network is important for dealing with the disaster, at the disaster site the relationship between professionals and spontaneous, unorganized volunteers who are willing to help is ambivalent. Previous researches showed that volunteers might bring helpful contributions, but they also might be potential liabilities to the response activities (Barsky et al., 2007; Rivera and Wood, 2016; Linnell, 2014). Volunteers can participate in a variety of support activities on the sites of disasters, such as providing information, clearing debris, collecting food or providing shelter. However, even if many volunteers are willing to help, they lack skills, training and adequate equipment, and might expose themselves to potential risks, thus becoming victims (Barsky et al., 2007).

\section{Methodology}

The research was conducted between September and November 2016. 567 questionnaires were sent by mail to a representative sample of City Halls from 22 counties, as follows: 26 municipalities, 51 cities and 490 communes. Out of 41 counties in Romania, we selected every other county to include in the sample, and then from each selected county we chose the municipality county residence, the every second 
city and commune from the list of all administrative units listed in the alphabetical order. In addition, we included in the sample all City Halls of the six administrative sectors of City of Bucharest, and the General City Hall of Bucharest. We accompanied the questionnaires by a letter addressed to the mayor in which we asked him/her to fill out the questionnaire or hand it out to the person responsible for the Voluntary Service for Emergency Situations established at the level of each City Hall. We assumed that the mayor or the person responsible for the Emergency Voluntary Service is a knowledgeable person and can provide a general overview of the behavior of residents in the case of an emergency situation.

The questionnaires included questions about the emergency situations faced in the past ten years (frequency, intensity, causes and impact on the community), the measures and strategies adopted to combat disasters, collaboration with different institutions for preparing for emergency situations, and about the opinion on the involvement of citizens before, during and after a major hazard event. Two questions aimed to measure the perception on the degree of individual and community resilience. We used a five-point Likert scale to measure the respondents' perception regarding the citizens' involvement during an emergency situation and regarding individual and community resilience. We used a list with multiple answers from where respondents could choose one for the questions about the intensity of the emergency situation, degree of anticipation, causes of the event, and the recovery time.

We received back 277 questionnaires, and the response rate was $48.85 \% .17 .6 \%$ of the respondents are females and $57.9 \%$ males (65 respondents did not disclose their gender). The majority of them are over 40 years old $(74.8 \%) .48 .9 \%$ of the respondents have lived for more than 10 years in the community, and $41.7 \%$ of them were born in the community, therefore they know well the community. The majority of the communities from where we received back questionnaires are rather small communities: $69.1 \%$ of them have a population between 2,001 and 10,000 people, while $18.0 \%$ have bellow 2,000 inhabitants. $60.1 \%$ of the communities are located at a distance greater than 30 kilometers away from the city county residence, and we received back questionnaires from 13 cities county residence. We received responses from 228 communes (82.31\%), 29 cities (10.46\%), 7 municipalities (2.52\%), and 13 county seats $(4.69 \%)$.

Out of 277 communities for which we obtained data, 216 faced at least one emergency situation in the past 10 years. The responses are divided by the development regions of the country as follows: North-East Region (22.02\%), South-East Region (12.63\%), South-Muntenia Region (10.46\%), South-Vest Oltenia Region (9.74\%), West Region (8.66\%), North-West Region (21.29\%), Center Region $(13.35 \%)$ and Bucharest-Ilfov Region (1.80\%).

\section{Results and discussions}

The first part of the research aimed to identify which are the threats that might affect the communities in the future. In this respect, respondents were asked to assess on a five-point Likert scale the probability that different hazards could affect their 
communities. The findings show that natural disasters, such as prolonged periods of drought, fire, earthquake and floods were perceived by the City Hall representatives as having higher probability of affecting their communities. Human caused accidents, such as work accidents, car accidents, nuclear accidents or terrorist attacks are perceived to have less probability of occurrence. When asked about how prepared communities were to different types of hazards, the respondents assessed their communities as being less prepared or not knowing the level of preparedness. For example, even though the respondents perceived that the earthquakes or prolonged periods of drought were probable to affect their communities, they felt that their communities were rather unprepared to such threats. On the other side, the respondents assessed that their communities were rather prepared for flooding or fires, which are more frequent hazards in Romania.

In order to analyze the perception on the citizens' behavior during emergency situations, we aimed to better understand the type of hazards that affected the communities in the past ten years, their causes, level of anticipation, intensity and their impact. Respondents from 216 out of 277 communities that answered the questionnaire declared that their settlements were affected by emergency situations. Flooding was the most frequently mentioned hazard, which affected 145 communities, fire 117 communities, prolonged periods of drought 80 communities, landslides 31 settlements, while earthquakes took place in 7 communities. In several cases, respondents reported that their communities faced more than one hazard in the past ten years.

A factor affecting the preparedness and the resilience of a community to an emergency situation is its capacity to anticipate the event. From this perspective, we asked the respondents to choose a statement that better described the level of preparedness when thinking to the most severe event that affected their community in the past ten years. In 82 cases, respondents answered that the event was unexpected, in 50 situations similar but less serious events took place previously; in 21 cases events of similar intensity took place in the past and they anticipated the occurrence of others in the future; while 43 communities were warned in advance about the imminence of the emergency situation.

When asked about the causes of the same severe event that affected their community in the past, City Hall representatives had to choose from a list of possible causes such as deforestation, work accidents, carelessness or incompetence of individuals or firms, lack of preventive measures, lack of financial resources or difficulties in implementing infrastructure projects for preventing the hazards. The respondents had the option to choose more than one cause of the hazard. In most cases, City Hall employees reported that deforestation was the main source of the hazard. This finding correlates with the fact that flooding affected most of the communities included in this research. In one quarter of the cases, incompetence or carelessness of people or firms, and the lack of infrastructure investments for preventing hazards were the causes of events. In the case of several communities the emergency situations were caused by a combination of natural and human-caused factors. 
We measured the estimated time for recovery of the communities after the emergency situation on a scale with four levels ranging from not very long time, medium recovery time, recovery was difficult and lengthy, and community could not overcome all problems. The estimated time for recovery of the communities shows that most of the emergency situations were of low or medium intensity. In 175 cases the respondents declared that the communities recovered shortly after the event or that communities needed a medium time for recuperation. In 19 cases respondents answered that the recovery was difficult and lengthy, while in 15 cases the communities could not overcome all problems generated by emergency situations. The most affected components of settlements were agricultural land, houses and roads.

Having this context laid out about the types, causes, anticipation level, intensity and impact of the emergency situations, we aimed to analyze the opinion of City Halls representatives on different types of manifestations of citizens' involvement throughout emergency events. In addition, we aimed to assess whether communities having a higher level of citizens' involvement in mitigating emergency situations were more resilient than those with a lower level of citizens' participation. In this regard, we asked the respondents to evaluate on a five-point Likert scale (ranging from 1 - total disagreement to 5 - total agreement) their agreement with several statements that characterize people's behavior during an emergency situation. The results are presented in Table 1.

Table 1: Statements that characterize the behavior of people during an emergency situation

\begin{tabular}{llccccc}
\hline & N & Mean & Median & Mode & $\begin{array}{c}\text { Std. } \\
\text { Deviation }\end{array}$ \\
\hline 1. Residents help each other during an emergency situation. & 211 & 3.87 & 4.00 & 4 & 0.872 \\
2. Residents help each other after an emergency situation. & 204 & 3.73 & 4.00 & 4 & 0.942 \\
3. Relatives help each other. & 210 & 4.26 & 4.00 & 4 & 0.649 \\
\hline 4. Neighbors help each other. & 211 & 4.15 & 4.00 & 4 & 0.745 \\
\hline $\begin{array}{l}\text { 5. } \\
\text { Residents help people who cannot cope alone with the }\end{array}$ & 209 & 3.88 & 4.00 & 4 & 0.855 \\
6. Residents of different ethnicities help each other. & 179 & 3.60 & 4.00 & 4 & 0.980 \\
7. Residents help rescue people who live in isolated areas. & 195 & 3.71 & 4.00 & 4 & 0.920 \\
8. People prefer to put their lives in danger than to leave & 193 & 2.87 & 3.00 & 2 & 1.105 \\
\hline $\begin{array}{l}\text { their home. } \\
\text { 9. Residents expect public authorities to help them rather }\end{array}$ & 198 & 3.14 & 3.00 & 2 & 1.179 \\
\hline
\end{tabular}

Source: Data collected by the author

The general perception of the respondents is that people tend to help each other during and after an emergency situation. The research showed an agreement among the majority of the respondents that relatives and neighbors tend to provide mutual support: the mean score for the statement 'Relatives help each other.' is 4.26 and the standard deviation is 0.649 , while for the statement 'Neighbors help each other.' is 4.15 and the standard deviation is 0.745 . This finding indicates the existence of strong bonding ties among emotionally connected people, which are important vehicles for 
providing support over difficult times. In addition, people tend to provide help to vulnerable social groups, such as people who cannot cope alone with emergency situations (elderly, children and disabled people) (mean score - 3.88; std. deviation 0.855 ) and people who live in isolated areas (mean score -3.71 ; std. deviation - 0.920).

The respondents' perception is divided with regard to the help people expect from public authorities in case of a hazard. City Hall representatives perceive that residents expect public authorities to help them rather than helping each other (mean score is 3.14). However, the mode having the value of 2 indicates that the majority of people tend to disagree with the statement. Nevertheless, standard deviation being 1.179 shows that the perceptions differ, and there are communities where mayors tend to blame residents for expecting public institutions to help them rather than helping each other. Still, there might be the case of severe emergency situations when people do not have the capacity and the means to help themselves and others, or it is not advisable for residents to intervene because they would be put at a higher risk.

The perceptions of the City Hall representatives are also divergent regarding the attitude of people to put their lives in danger rather than leaving their homes (mean score is 2.87 and std. deviation is 1.105). People might consider the home as their most valuable property, and therefore they are not willing to leave it out of fear of losing it. No statistically significant correlation was found between the reluctance to leave the home and the size of the community or the distance from a major urban center, which indicates a general preference among people to safeguard their properties. However, a weak positive correlation was found between the reluctance to leave the home and the level of anticipation of an emergency situation (Pearson correlation -0.138 and sig. 0.030). The more predictable are the events the more willing are people to leave their homes, since they might have a better understanding on the danger they might be exposed to.

Another objective of the research was to analyze different types of support people provide each other during an emergency situation. We asked City Hall representatives to evaluate on a five-point Likert scale (ranging from 1 - total disagreement to 5 - total agreement) their agreement with several statements that characterize the support residents provide each other during an emergency situation (Table 2 summarizes the findings). Warning other people of the imminent occurrence of an emergency situation is the most frequent type of support (mean score -4.04 , std. deviation - 0.811). In addition, respondents reported that people get involved in search and rescue activities, as they contribute to saving lives of other people (mean score 3.99, std. deviation - 0.861), and saving the belongings of people affected by a hazard (mean score -3.85 , std. deviation - 0.841). During an emergency situation, residents provide emotional support to each other (mean score - 3.78, std. deviation - 0.913), and take care of the children whose families were affected by a calamity (mean score -3.78 , std. deviation -0.938 ). The respondents perceived that people tend to provide financial and material support, and to get involved in helping rebuild public infrastructure, but to a lesser degree. 
Table 2: Types of support provided by residents during an emergency situation

\begin{tabular}{lllllc}
\hline & N & Mean & Median & Mode & $\begin{array}{c}\text { Std. } \\
\text { Deviation }\end{array}$ \\
\hline 1. $\begin{array}{l}\text { Residents announce each other on the imminent } \\
\text { occurrence of an emergency. }\end{array}$ & 201 & 4.04 & 4.00 & 4 & 0.811 \\
2. Residents provide financial support to people in need. & 193 & 2.76 & 3.00 & 2 & 1.019 \\
\hline 3. Residents provide material support to people in need. & 197 & 3.05 & 3.00 & 2 & 1.009 \\
\hline 4. Residents provide emotional support to each other. & 194 & 3.78 & 4.00 & 4 & 0.913 \\
\hline $\begin{array}{l}\text { Residents help saving the belongings of people affected } \\
\text { by a calamity. }\end{array}$ & 208 & 3.85 & 4.00 & 4 & 0.841 \\
6. Residents participate to saving lives of people in danger. & 202 & 3.99 & 4.00 & 4 & 0.861 \\
$\begin{array}{l}\text { 7. Residents take care of children whose families were } \\
\text { affected by a calamity. }\end{array}$ & 196 & 3.78 & 4.00 & 4 & 0.938 \\
\hline $\begin{array}{l}\text { 8. Residents help with physical work to rebuild the houses } \\
\text { destroyed by a calamity. }\end{array}$ & 200 & 3.39 & 4.00 & 4 & 1.046 \\
9. Residents help rebuild public infrastructure. & 182 & 2.59 & 2.00 & 2 & 1.072 \\
\hline
\end{tabular}

Source: Data collected by the author

We asked the respondents to evaluate their level of resilience and the resilience level of their community on a five-point Likert scale ranging from 1 (minimum) to 5 (maximum). We provided the respondents with a definition of resilience as the capacity to rapidly return to the normal state after the occurrence of an emergency situation. The mean score for the level of individual resilience was 3.83, while for the level of community resilience was 3.49 (Table 3 ).

Table 3: Perception on the level of personal and community resilience

\begin{tabular}{lccccc}
\hline & N & Mean & Median & Mode & $\begin{array}{c}\text { Std. } \\
\text { deviation }\end{array}$ \\
\hline 1. Level of individual resilience & 192 & 3.83 & 4.00 & 4 & .808 \\
2. Level of community resilience & 188 & 3.49 & 3.00 & 3 & .756 \\
\hline
\end{tabular}

Source: Data collected by the author

We aimed to analyze any correlation between the level of community resilience and the perception regarding the level of preparedness in the case of an emergency situation. We found that the level of community resilience is positively correlated with the perception on the existence of equipment and necessary materials for emergency intervention $\left(0.223^{* *}\right)$, and the perception on how well trained are members of Volunteer Emergency Service $\left(0.255^{* *}\right)$ (see Table 4$)$; however, the relationship is rather low. The finding shows that if the City Hall representatives perceive that the community has the necessary equipment and trained personnel for emergency interventions, then they perceive the community as being better prepared to face such threats.

In addition, we aimed to test if there is a relation between the perception on community resilience and the perception on the support among residents. The research showed that City Hall representatives perceived that communities were more resilient when residents tended to help each other more during and after an emergency 
Table 4: Correlation between the level of community resilience and the perception on the existence of equipment and necessary materials, and well as trained volunteers

\begin{tabular}{llcc}
\hline & & $\begin{array}{c}\text { The settlement has the equipment } \\
\text { and the materials necessary } \\
\text { for emergency intervention }\end{array}$ & $\begin{array}{c}\text { People who are members of } \\
\text { Volunteer Emergency Service are trained } \\
\text { to intervene in emergency situations. }\end{array}$ \\
\hline $\begin{array}{l}\text { Level of } \\
\text { community }\end{array}$ & Pearson Correlation & $.223^{* *}$ & $.255^{* *}$ \\
resilience & $\mathrm{N}$ & .002 & .000 \\
\hline
\end{tabular}

Note: ${ }^{* *}$. Correlation is significant at the 0.01 level (2-tailed).

Source: Data collected by the author

situation (see Table 5). However, when residents expect public authorities to help them rather than helping each other, the level of community resilience is perceived to be lower. In addition, communities are perceived more resilient when people of different ethnicities help each other. This might be the case when the more marginalized group within a community, such as Roma population, is supported during and

Table 5: Correlation between level of community resilience and the behavior of residents during an emergency situation

\begin{tabular}{|c|c|c|}
\hline & & $\begin{array}{l}\text { Level of community } \\
\text { resilience }\end{array}$ \\
\hline 1. Residents help each other during an emergency situation. & $\begin{array}{l}\text { Pearson Correlation } \\
\text { Sig. (2-tailed) } \\
\mathrm{N}\end{array}$ & $\begin{array}{l}.394^{* *} \\
.000 \\
184\end{array}$ \\
\hline 2. Residents help each other after an emergency situation. & $\begin{array}{l}\text { Pearson Correlation } \\
\text { Sig. (2-tailed) } \\
\mathrm{N}\end{array}$ & $\begin{array}{l}.426^{* *} \\
.000 \\
178\end{array}$ \\
\hline 3. Relatives help each other. & $\begin{array}{l}\text { Pearson Correlation } \\
\text { Sig. (2-tailed) } \\
\text { N }\end{array}$ & $\begin{array}{l}.332 * \\
.000 \\
183\end{array}$ \\
\hline 4. Neighbors help each other. & $\begin{array}{l}\text { Pearson Correlation } \\
\text { Sig. (2-tailed) } \\
\mathrm{N}\end{array}$ & $\begin{array}{l}.320 * \\
.000 \\
182\end{array}$ \\
\hline $\begin{array}{l}\text { Residents help people who cannot cope alone with the } \\
\text { emergency situation (eg. elderly, children, disabled). }\end{array}$ & $\begin{array}{l}\text { Pearson Correlation } \\
\text { Sig. (2-tailed) } \\
\text { N }\end{array}$ & $\begin{array}{l}.397^{* *} \\
.000 \\
180\end{array}$ \\
\hline 6. Residents of different ethnicities help each other. & $\begin{array}{l}\text { Pearson Correlation } \\
\text { Sig. (2-tailed) } \\
\mathrm{N}\end{array}$ & $\begin{array}{l}.419^{* *} \\
.000 \\
155\end{array}$ \\
\hline 7. Residents help rescue people who live in isolated areas. & $\begin{array}{l}\text { Pearson Correlation } \\
\text { Sig. (2-tailed) } \\
\mathrm{N}\end{array}$ & $\begin{array}{l}.342 \\
.000 \\
171\end{array}$ \\
\hline $\begin{array}{l}\text { 8. Residents expect public authorities to help them } \\
\text { rather than helping each other. }\end{array}$ & $\begin{array}{l}\text { Pearson Correlation } \\
\text { Sig. (2-tailed) } \\
\text { N }\end{array}$ & $\begin{array}{r}-.258^{* *} \\
.001 \\
173\end{array}$ \\
\hline
\end{tabular}

Note: ${ }^{* *}$. Correlation is significant at the 0.01 level (2-tailed).

Source: Data collected by the author 
after a hazard. This finding indicates that City Hall representatives perceive that their communities can overcome the periods of distress caused by emergency situations when the support among residents is more intense, and therefore community social capital is stronger.

The research showed an association between the level of community resilience and different forms of support that people provide each other. We found that the existence of strong ties among the residents of a community is correlated with higher perception on community resilience (see Table 6). The higher is the emotional support provided by the residents, the higher is the perception of community resilience (Pearson correlation is 0.401 ). In addition, the more people announce each other on the occurrence of an emergency, a community is perceived as being more resilient (Pearson correlation is 0.398). In addition, City Hall representatives perceived that their communities had a higher capacity to rapidly return to the normal state after the occurrence of an emergency situation if residents provided different forms of support to each other.

Table 6: Correlation between level of community resilience and different forms of support among residents

\begin{tabular}{|c|c|c|c|}
\hline & & & $\begin{array}{l}\text { Level of community } \\
\text { resilience }\end{array}$ \\
\hline 1. & $\begin{array}{l}\text { Residents announce each other on the imminent } \\
\text { occurrence of an emergency. }\end{array}$ & $\begin{array}{l}\text { Pearson Correlation } \\
\text { Sig. (2-tailed) } \\
\text { N }\end{array}$ & $\begin{array}{l}.398^{* *} \\
.000 \\
180\end{array}$ \\
\hline 2. & Residents provide financial support to people in need. & $\begin{array}{l}\text { Pearson Correlation } \\
\text { Sig. (2-tailed) } \\
\mathrm{N}\end{array}$ & $\begin{array}{l}.284^{* *} \\
.000 \\
170\end{array}$ \\
\hline 3. & Residents provide material support to people in need. & $\begin{array}{l}\text { Pearson Correlation } \\
\text { Sig. (2-tailed) } \\
\text { N }\end{array}$ & $\begin{array}{l}.326^{* *} \\
.000 \\
174\end{array}$ \\
\hline 4. & Residents provide emotional support to each other. & $\begin{array}{l}\text { Pearson Correlation } \\
\text { Sig. (2-tailed) } \\
\mathrm{N}\end{array}$ & $\begin{array}{l}.401^{* *} \\
.000 \\
171\end{array}$ \\
\hline 5. & $\begin{array}{l}\text { Residents help saving the belongings of people } \\
\text { affected by a calamity. }\end{array}$ & $\begin{array}{l}\text { Pearson Correlation } \\
\text { Sig. (2-tailed) } \\
\text { N }\end{array}$ & $\begin{array}{l}.307^{* *} \\
.000 \\
184\end{array}$ \\
\hline 6. & $\begin{array}{l}\text { Residents participate to saving lives of people in } \\
\text { danger. }\end{array}$ & $\begin{array}{l}\text { Pearson Correlation } \\
\text { Sig. (2-tailed) } \\
\text { N }\end{array}$ & $\begin{array}{l}.312^{* *} \\
.000 \\
178\end{array}$ \\
\hline 7. & $\begin{array}{l}\text { Residents take care of children whose families were } \\
\text { affected by a calamity. }\end{array}$ & $\begin{array}{l}\text { Pearson Correlation } \\
\text { Sig. (2-tailed) } \\
\text { N }\end{array}$ & $\begin{array}{l}.338^{* *} \\
.000 \\
175\end{array}$ \\
\hline 8. & $\begin{array}{l}\text { Residents help with physical work to rebuild the houses } \\
\text { destroyed by a calamity. }\end{array}$ & $\begin{array}{l}\text { Pearson Correlation } \\
\text { Sig. (2-tailed) } \\
\text { N }\end{array}$ & $\begin{array}{l}.337^{* *} \\
.000 \\
180\end{array}$ \\
\hline & Residents help rebuild public infrastructure. & $\begin{array}{l}\text { Pearson Correlation } \\
\text { Sig. (2-tailed) } \\
\text { N }\end{array}$ & $\begin{array}{l}.351^{* *} \\
.000 \\
162\end{array}$ \\
\hline
\end{tabular}

Note: ${ }^{* *}$. Correlation is significant at the 0.01 level (2-tailed).

Source: Data collected by the author 
Furthermore, we built a regression model for the communities that faced an emergency situation in the past (216 communities) in order to identify how much of the perception of the City Hall representatives on community resilience is influenced by the following independent variables: the perception on the behavior of people during an emergency situation (seven variables/statements), the perception on the types of support provided by residents during an emergency situation (nine variables/statements), the perception on the existence of equipment, necessary materials, and the level of training of volunteers, and the perception on individual resilience (see Table 7). The model we constructed explains $48.8 \%$ of the variance of community resilience and it is statistically significant. The independent variables we found to have a statistically significant influence on community resilience are: a) 'Residents help each other during an emergency situation.' (Beta coefficient is 0.472 and sig. is 0.002 ); b) 'Residents of different ethnicities help each other.' (Beta coefficient is 0.219 and sig. is 0.043), and c) level of individual resilience (Beta coefficient is 0.376 and sig. is 0.000 ).

Table 7: Factors that influence the perception of City Hall representatives on community resilience in case of emergency situation

\begin{tabular}{|c|c|c|c|c|c|}
\hline & \multicolumn{2}{|c|}{$\begin{array}{l}\text { Unstandardized } \\
\text { Coefficients }\end{array}$} & \multirow{2}{*}{$\begin{array}{c}\begin{array}{c}\text { Stand. } \\
\text { Coeffs. }\end{array} \\
\text { Beta }\end{array}$} & \multirow[t]{2}{*}{$\mathrm{t}$} & \multirow[t]{2}{*}{ Sig. } \\
\hline & B & Std. Error & & & \\
\hline Constant & -.102 & .433 & & -.235 & .814 \\
\hline Level of individual resilience is .... & .357 & .072 & .376 & 4.964 & .000 \\
\hline Residents help each other during an emergency situation. & .409 & .130 & .472 & 3.140 & .002 \\
\hline Residents help each other after an emergency situation. & -.199 & .133 & -.249 & -1.492 & .139 \\
\hline Relatives help each other. & .236 & .151 & .198 & 1.561 & .122 \\
\hline Neighbors help each other. & -.069 & .139 & -.068 & -.498 & .620 \\
\hline $\begin{array}{l}\text { Residents help people who cannot cope alone with the } \\
\text { emergency situation (e.g. elderly, children, disabled). }\end{array}$ & .100 & .113 & .115 & .884 & .379 \\
\hline Residents of different ethnicities help each other. & .173 & .084 & .219 & 2.052 & .043 \\
\hline Residents help rescue people who live in isolated areas. & .089 & .099 & .105 & .893 & .374 \\
\hline $\begin{array}{l}\text { Residents announce each other on the imminent occurrence } \\
\text { of an emergency. }\end{array}$ & .102 & .090 & .111 & 1.131 & .261 \\
\hline Residents provide financial support to people in need. & .057 & .098 & .071 & .582 & .562 \\
\hline Residents provide material support to people in need. & .118 & .102 & .146 & 1.162 & .248 \\
\hline Residents provide emotional support to each other. & .021 & .078 & .024 & .267 & .790 \\
\hline $\begin{array}{l}\text { Residents help saving the belongings of people affected } \\
\text { by a calamity. }\end{array}$ & -.173 & .109 & -.194 & -1.591 & .115 \\
\hline Residents participate to saving lives of people in danger. & -.132 & .107 & -.151 & -1.233 & .221 \\
\hline $\begin{array}{l}\text { Residents take care of children whose families were affected } \\
\text { by a calamity. }\end{array}$ & -.165 & .093 & -.193 & -1.761 & .081 \\
\hline $\begin{array}{l}\text { Residents help with physical work to rebuild the houses } \\
\text { destroyed by a calamity. }\end{array}$ & -.025 & .101 & -.033 & -.243 & .809 \\
\hline Residents help rebuild public infrastructure. & .039 & .065 & .055 & .604 & .547 \\
\hline $\begin{array}{l}\text { The settlement has the equipment and the materials necessary } \\
\text { for emergency intervention. }\end{array}$ & -.028 & .066 & -.037 & -.425 & 672 \\
\hline $\begin{array}{l}\text { People who are members of Volunteer Emergency Service are } \\
\text { trained to intervene in emergency situations. }\end{array}$ & .047 & .042 & .097 & 1.128 & .262 \\
\hline
\end{tabular}




\begin{tabular}{lc}
\hline & Model statistics \\
\hline$R$ & 0.758 \\
R square & 0.574 \\
Adjusted R Square & 0.488 \\
Std. Error of the Estimate & 0.540 \\
Sum of Squares & 36.938 \\
df & 19 \\
Mean Square & 1.944 \\
F & 6.664 \\
Sig. & 0.000 \\
\hline
\end{tabular}

Source: Data collected by the author

Based on the results presented in Table 7 we can conclude that the fact that people help each other influences in a moderate degree the level of community resilience, while the existence of tolerance among people of different ethnicities and the level of individual resilience of City Hall representatives have a low influence.

\section{Conclusion}

The research aimed to identify whether communities in which social capital is higher are more resilient in the case of natural and human caused disasters. We found that City Hall representatives indeed perceive that their communities have a higher capacity to recover after the occurrence of an emergency situation if the level of social capital is higher. The manifestation of social capital takes the following forms: people announce each other on the imminent occurrence of an emergency, contribute to saving lives and belongings of people, and take care of children whose families were affected by a calamity. The support is more frequent among emotionally connected people, such as relatives and neighbors. In addition, people tend to provide help to vulnerable groups, such as people who cannot cope alone with emergency situations and people who live in isolated areas. Communities are perceived to be more resilient if residents are tolerant as people of different ethnicities help each other.

The representatives of local authorities perceive that citizens expect public authorities to help them rather than helping each other. This finding is important because it shows that even though people tend to help each other in general, people still expect support from public authorities. Respondents' opinions are split regarding the attitude of people to put their lives in danger rather than leave their homes. People are not willing to leave their homes in case of a disaster because they consider the home the most valuable property; however, the more predictable are the events the more willing are people to leave their homes, since they might have a better understanding on the dangers they might be exposed to. The research showed that communities are perceived as being more resilient if people perceive that communities have the necessary equipment to cope with distress situations.

The research revealed that communities having a stronger bonding capital can overcome more easily periods of distress. We recommend local authorities to 
strengthen the ties and tolerance among residents in order to increase the preparedness of communities to overcome natural and man-caused hazards. However, the help provided by unorganized members of the community is both beneficial and unsafe, therefore communities should plan in advance how to manage the involvement of residents without exposing them to additional risks.

The findings of this research should be analyzed carefully because we measured community resilience as the perception of City Hall representatives (either mayors or employees responsible with emergency situations). Therefore, it is the perception of only one individual about an entire community, which is a subjective evaluation on community resilience rather than an objective one. Nonetheless, the results are still valid because the majority of the communities from where we received responses are small, and the respondents are knowledgeable people who lived for a long period of time in their communities.

\section{References:}

1. Adger, W.N., 'Social and Ecological Resilience: Are They Related?', 2000, Progress in Human Geography, vol. 24, no. 3, pp. 347-364.

2. Aldrich, D.P. and Meyer, M.A., 'Social Capital and Community Resilience', 2015, American Behavioral Scientist, vol. 59, no. 2, pp. 254-269.

3. Aldrich, D.P., 'Fixing Recovery: Social Capital in Post-Crisis Resilience', Department of Political Science Faculty Publications, Paper 3, 2010, [Online] available at https:// pdfs.semanticscholar.org/da5b/2020ee7aa412abd9a5552eaff11650c1ee4a.pdf, accessed on July 20, 2016.

4. Aldrich, D.P., 'Ties that Bond, Ties that Build: Social Capital and Governments in Post Disaster Recovery', 2011, Studies in Emergent Order, vol. 4, pp. 58-68.

5. Armaș, I., 'Multi-criteria Vulnerability Analysis to Earthquake Hazard of Bucharest, Romania', 2012, Natural Hazards, vol. 63, no. 2, pp. 1129-1156.

6. Armaș, I., 'Social Vulnerability and Seismic Risk Perception. Case Study: The Historic Center of the Bucharest Municipality/Romania', 2008, Natural Hazards, vol. 47, no. 3, pp. 397-410.

7. Barsky, L.E., Trainor, J.E., Torres, M.R. and Aguirre, B.E., 'Managing Volunteers: FEMA's Urban Search and Rescue Programme and Interactions with Unaffiliated Responders in Disaster Response', 2007, Disasters, vol. 31, no. 4, pp. 495-507.

8. Besser, T., 'Resilient Small Rural Towns and Community Shocks', 2013, Journal of Rural and Community Development, vol. 8, no. 1, pp. 117-134.

9. Bihari, M. and Ryan, B., 'Influence of Social Capital on Community Preparedness for Wildfires', 2012, Landscape and Urban Planning, vol. 106, no. 3, pp. 253-261.

10. Buckle, P., 'Assessing Social Resilience', in Paton, D. and Johnston, D., Disaster Resilience: An Integrated Approach, Illinois: Charles C. Thomas Publisher, 2006, pp. 88-104.

11. Chamlee-Wright, E. and Storr, V.H., 'Social Capital and Collective Narratives and Post-disaster Community Recovery', 2011, The Sociological Review, vol. 59, no. 2, pp. 266-282.

12. Chamlee-Wright, E., The Cultural and Political Economy of Recovery: Social Learning in a Post-disaster Environment, New York: Routledge, 2010. 
13. Cheshire, L, Esparcia, J. and Shucksmith, M., 'Community Resilience, Social Capital and Territorial Governance', 2015, Ager. Journal of Depopulation and Rural Development Studies, vol. 18, pp. 7-38.

14. Cox, R.S. and Hamlen, M., 'Community Disaster Resilience and the Rural Resilience Index', 2015, American Behavioral Scientist, vol. 59, no. 2, pp. 220-237.

15. Crowe, P.R., Foley, K. and Collier, M.J., 'Operationalizing Urban Resilience through a Framework for Adaptive Co-Management and Design: Five Experiments in Urban Planning Practice and Policy', 2016, Environmental Science and Policy, vol. 62, pp. 112119.

16. Cutter, S.L., Burton, C.G. and Emrich, C.T., 'Disaster Resilience Indicators for Benchmarking Baseline Conditions', 2010, Journal of Homeland Security and Emergency Management, vol. 7, no. 1, pp. 1-22.

17. Hanger, S., Linnerooth-Bayer, J., Surminski, S., Nenciu-Posner, C., Lorant, A., Ionescu, R. and Patt, A., 'Insurance, Public Assistance, and Household Flood Risk Reduction: A Comparative Study of Austria, England, and Romania', 2018, Risk Analysis, vol. 38, no. 4, pp. 680-693.

18. Hawke, S., Girard, J. and Carr, J., 'How Government's Actions after a Disaster Affect Long-Term Civic Engagement. Shifting Opportunities and Motivation for Civic Participation in Christchurch, New Zeeland', in Downey, D.C. (ed.), Cities and Disasters, Boca Raton, FL: CRC Press, 2016, pp. 147-172.

19. Hung, H., Yang, C.-Y., Chien, C.-Y. and Liu Y.-C., 'Building Resilience: Mainstreaming Community Participation into Integrated Assessment of Resilience to Climatic Hazards in Metropolitan Land Use Management', 2016, Land Use Policy, vol. 50, pp. 48-58.

20. Islam, R. and Walkerden, G., 'How Bonding and Bridging Networks Contribute to Disaster Resilience and Recovery on the Bangladeshi Coast', 2014, International Journal of Disaster Risk Reduction, vol. 10, part A, pp. 281-291.

21. Kimhi, S., 'Levels of Resilience: Associations among Individuals, Community, and National Resilience', 2016, Journal of Health Psychology, vol. 21, no. 2, pp. 164-170.

22. Leykin, D., Lahad, M., Cohen, O., Goldberg, A. and Aharonson-Daniel, L., 'Conjoint Community Resiliency Assessment Measure-28/10 Items (CCRAM28 and CCRAM10): A Self-report Tool for Assessing Community Resilience', 2013, American Journal of Community Psychology, vol. 52, no. 3-4, pp. 313-323.

23. Linnell, M., 'Citizen Response in Crisis: Individual and Collective Efforts to Enhance Community Resilience', 2014, Human Technology, vol. 10, no. 2, pp. 68-94.

24. Maguire, B. and Cartwright, S., 'Assessing a Community's Capacity to Manage Change: A Resilience Approach to Social Assessment', Australian Government, Bureau of Rural Sciences, 2008, [Online] available at http://data.daff.gov.au/brs/brsShop/ data/dewha_resilience_sa_report_final_4.pdf, accessed on March 25, 2014.

25. Masterson, J.H., Peacock, W.G., Van Zandt, S.S., Grover, H., Schwarz, L.F. and Cooper, J.T., Planning for Community Resilience. A Handbook for Reducing Vulnerability to Disasters, Washington: Island Press, 2014.

26. Meerow, S., Newell, J.P. and Stults, M., 'Defining Urban Resilience: A Review', 2016, Landscape and Urban Planning, vol. 147, pp. 38-49.

27. Nakagawa, Y. and Shaw, R., 'Social Capital: A Missing Link to Disaster Recovery', 2004, International Journal of Mass Emergencies and Disasters, vol. 22, no. 1, pp. 5-34. 
28. Nirupa, N. and Maula, A., 'Engaging Public for Building Resilient Communities to Reduce Disaster Impact', 2013, Natural Hazards, vol. 66, no. 1, pp. 51-59.

29. Norris, F.N., Stevens, S.P., Pfefferbaum, B., Wyche, K.F. and Pfefferbaum, R.L., 'Community Resilience as a Metaphor, Theory, Set of Capacities, and Strategy for Disaster Readiness', 2008, American Journal of Community Psychology, vol. 41, no. 1-2, pp. 127150.

30. Orencio, P.M. and Fujii, M., 'A Localized Disaster-resilience Index to Assess Coastal Communities Based on An Analytic Hierarchy Process (AHP)', 2013, International Journal of Disaster Risk Reduction, vol. 3, pp. 62-75.

31. Radu, B., Reziliența fostelor comunități miniere (Resilience of Former Mining Communities), Cluj-Napoca: Presa Universitară, 2015.

32. Rivera, J.D. and Wood, Z.D., 'Disaster Relief Volunteerism: Evaluating Cities' Planning for the Usage and Management of Spontaneous Volunteers', 2016, Journal of Emergency Management, vol. 14, no. 2, pp. 127-138.

33. Sherrieb, K., Norris, F.H. and Galea, S., 'Measuring Capacities for Community Resilience', 2010, Social Indicators Research, vol. 99, no. 2, pp. 227-247.

34. Spialek, M.L., Czlapinski, H.M. and Houston, J.B., 'Disaster Communication Ecology and Community Resilience Perceptions following the 2013 Central Illinois Tornadoes', 2016, International Journal of Disaster Risk Reduction, vol. 17, pp. 154-160.

35. Storr, V.H. and Haeffele-Balch, S., 'Post-disaster Community Recovery in Heterogeneous, Loosely Connected Communities', 2012, Review of Social Economy, vol. 70, no. 3, pp. 295-314. 